\title{
Identification of a Plausible Inhibitor of SARS-Cov 2 Protease (6LU7) and the Spike Envelope Glycoprotein (6MOJ) from Active Compounds of Nigella sativa: An In- silico Approach
}

\author{
Sardar Hussain 1(D), Koralahalli Parameshwarappa Komal ${ }^{2} \mathbb{D}$, Sreenivasa Ennaganti ${ }^{3}$, \\ Jafar Khaliq Lone ${ }^{4}$ (D), Khalid Rehman Hakeem ${ }^{\text {,* (D) }}$

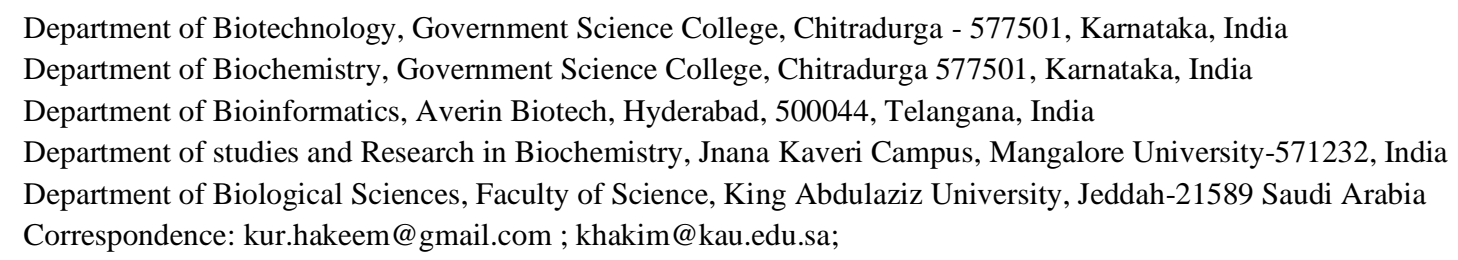

Scopus Author ID 36993011800

Received: 13.09.2021; Revised: 15.10.2021; Accepted: 18.10.2021; Published: 26.10.2021

Abstract: SARS-CoV-2, the recent disease outbreak causing respiratory tract illness, raised as the global health burden that has caused significant morbidity and mortality worldwide. In the ongoing transmission of this pandemic virus, its control is very challenging due to the lack of specific treatment. The compelling situation feels the necessity for the use of all assets to cure this disease. SARS-CoV-2, main protease, and spike envelope glycoprotein are important determinants in the infectious virus process, and targeting these proteins is gaining importance in anti-CoV drug design. In these conceptual circumstances, an attempt has been made to suggest an in silico molecular docking approach to identify new probable leads from the active constituents from Nigella sativa $\mathrm{L}$ against protein target main protease(6LU7) and spike envelope glycoprotein(6MOJ). Our results indicate that Nigellicine and Nigellicimine N-Oxide towards main protease and Nigellamine A5 and Nigellamine A1 towards spike glycoprotein has potential antiviral protein binding affinity among others forming good interactions. Thus, these compounds may be considered to be potential inhibitors against SARS-CoV-2 but need to be explored for further evaluations are recommended.

Keywords: antiviral; Nigella sativa L; main protease; spike glycoprotein; SARS-CoV-2.

(C) 2021 by the authors. This article is an open-access article distributed under the terms and conditions of the Creative Commons Attribution (CC BY) license (https://creativecommons.org/licenses/by/4.0/).

\section{Introduction}

Novel coronavirus disease (COVID-19), referred to as neo-coronary pneumonia caused by severe acute respiratory syndrome-related coronavirus 2 (SARS-CoV-2), has become a pandemic threat to public health [1]. The epicenter of the outbreak was located in Wuhan, Hubei Province, China. This is a zoonotic coronavirus, highly transmissible, and can lead to mild to severe respiratory tract infections [2]. It is a respiratory disorder causing fever, fatigue, dry cough, muscle aches, shortness of breath, and some instances lead to pneumonia [3]. In serious conditions, it causes ARDS-Acute Respiratory Distress Syndrome, i.e., a lung inflammation so severe that fluid builds up around and within the lungs, which can cause septic shock due to a dramatic fall in blood pressure and bodily organs are starved for oxygen. After 
infection with the virus, the symptoms are likely to appear within two to fourteen days, depending on the person's age and weak immunity due to other illnesses like diabetes, asthma, heart ailment, etc. [4]. The spread of this virus has drawn great attention and created concern worldwide.

Similarly, there have been two coronavirus-related crises in humans since 2003. Severe acute respiratory syndrome coronavirus (SARS-CoV) broke out in 2003, and the Middle East Respiratory Syndrome Coronavirus (MERS-CoV) emerged in the Arabian Peninsula in 2012 with a fatality rate of $35 \%$ [5]. The confirmed COVID-19 cases by $15^{\text {th }}$ April 2020 reported to 1914916 across 210 countries and territories with total death of 123,010 [6].

Coronavirus $(\mathrm{CoV})$ is a genus of the Coronaviridae family and is a relatively large virus containing a single-stranded positive-sense RNA genome encapsulated within a membrane envelope. The viral membrane is studded with glycoprotein spikes that give coronaviruses their crown-like appearance. There are four classes of coronavirus designed as alpha, beta, gamma, and delta. The novel SARS-COV-2 is a betacoronavirus from the subgenus Sarbecovirus $[7,8]$. The genome SARS-COV-2 encodes many important proteins for its replication in the host genome, viz. the nucleocapsid protein, Spike (S) protein, Envelope $€$ protein, Membrane (M) protein, and coronavirus proteases, PLpro and CoV M pro [9]. The genome of this virus acts like a messenger RNA when it infects a cell and directs the synthesis of two long polyproteins that include the machinery that the virus needs to replicate new viruses. The protease enzyme is essential for processing the polypeptide into functional proteins. Upon entrance to the host cell, the viral genome is released and subsequently translated into viral polyproteins using host cell translation machinery, cleaved into effector proteins by viral theses proteases [10]. The $\mathrm{CoV} \mathrm{M}$ pro main protease plays a critical role in the virus replication process. The structure of the Mpro enzyme forms a dimer whose each monomer comprises three domains: Domain I (residues 1-101) and II (102-184) consists of an antiparallel beta-barrel, and the alpha-helical domain III (residues 201-301) is required for the enzymatic activity [11].

The entry into the host cell by the Coronaviruses is usually mediated by spike (S) glycoprotein. These proteins are responsible for virus replication in human host cells. Spike proteins latch onto human cells and undergo a structural change, which results in the fusion of the viral membrane with the human host cell membrane. Thus, the viral genes enter the host cell and produce more viruses after copying its genome [12]. SARS-CoV-2 spike proteins bind to the receptor proteins on the human cell surface, known as angiotensin-converting enzyme 2 (ACE2). The atomic-level structure of SARS-CoV-2 spike proteins has a Receptor Binding Domain (RBD) for binding to host human cells. Receptor Binding Domain (RBD) of spike glycoprotein (RBD-S) can bind to the ACE2 receptor at the Protease Domain (PD) of the human host cell, causing viral infection $[13,14]$ SARS-CoV-2 spike protein is 10-20 times more likely to bind with ACE2 on human cells than other, which enable SARS-CoV-2 to spread more easily. Thus, by inhibiting the Mpro protease, we can stop virus replication while inhibition of ACE2 catalytic pocket by small molecules could change the conformation of ACE2 so that it could block SARS-CoV-2 entry inside the host cells through ACE2[15]. Therefore, Mpro, protease as a target to inhibit virus replication and ACE2 receptor from blocking entry SARS-CoV-2.

Medicinal plants have been used to cure diseases for many centuries in different indigenous systems of medicine and folk medicines. Moreover, medicinal plants are also used to prepare herbal medicines as they are considered safe compared to modern allopathic medicines. Nigella sativa ( $N$. sativa) (Family Ranunculaceae) is emerging as a miraculous herb 
with a rich historical and religious basis among medicinal plants. Since a variety of studies have proven its broad range of pharmacological properties [16]. Black seed is the renowned name for $N$. sativa. $N$. sativa has been investigated widely for its biological and pharmaceutical potential and has been found to have a wide range of actions.viz. as a diuretic, antihypertensive, antidiabetic, anticancer and immunomodulatory, analgesic, antimicrobial, antioxidant, anthelmintics, analgesics and anti-inflammatory, gastroprotective, hepatoprotective, renal protective, spasmolytic, bronchodilator properties. N. sativa seeds are commonly used to cure ailments such as bronchitis, asthma, diarrhea, rheumatism, and skin issues. It's also used as a liver tonic, digestive, anti-diarrheal, appetite stimulant, emmenagogue (to promote milk supply in nursing mothers), parasite fighter, and immune system support [17-22].

Keeping the current situation of pandemic COVID-19 in mind and diverse therapeutically use of N. sativa, using in silico approaches, the present study efforted to explore the possibility of this plant active constituents as probable drug leads alternative to prevent this deadly pandemic COVID-19. For this study, the two-drug targets, main protease, and spike protein receptor-binding domain are chosen, and docking studies are done using Molecular Operating Environment software (MOE) docking software. The present study will provide other researchers with important investigation ways to identify new COVID-19 treatments and the use of natural products.

\section{Materials and Methods}

\subsection{Target protein retrieval.}

The X-ray crystal structures of the main protease (Fig. 1) in complex with an inhibitor N3 (PDB ID: 6LU7) and spike receptor-binding domain bound with ACE2(PDBID: 6M0J) of SARS-CoV-2 was retrieved from Protein Data Bank with a resolution of $2.16 \AA$ and $2.45 \AA$, respectively.
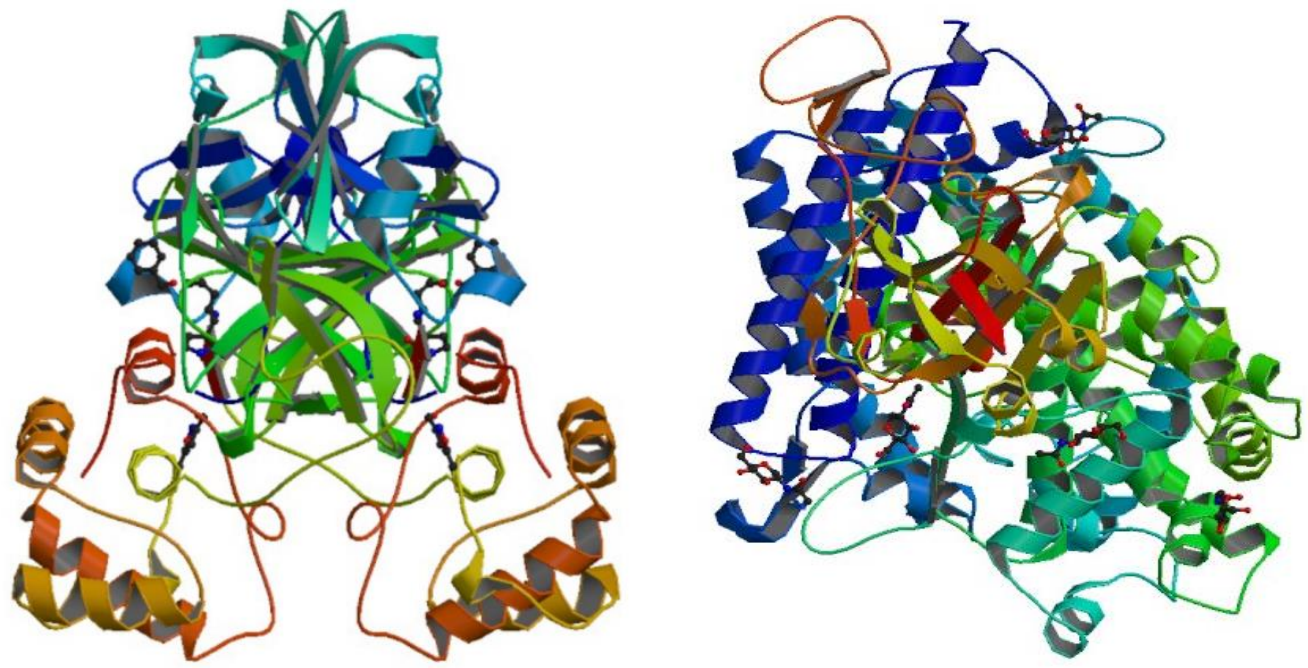

Figure 1. The X-ray crystal structure of (a) main protease in complex with an inhibitor N3 (PDB ID :6LU7) and (b) spike receptor-binding domain bound with ACE2 (PDB ID: 1M0J) of SARS-CoV-2

\subsection{Protein preparation.}

The 3D coordinates of both the proteins are loaded into MOE, the water molecules and heteroatoms were eliminated, and polar hydrogens were added to the structure with their standard geometry followed by their energy minimization. The energy of the protein molecule was minimized using the Energy minimization algorithm of the MOE tool. A temperature of 
$300 \mathrm{~K}$ and a salt concentration of 0.1 and $\mathrm{pH} 7$ were specified in the implicit solvated environment to carry out the protonation process. Then, the structure was energy-minimized in the MMFF94x force field to an RMS gradient of 0.05. Energy minimization was terminated when the root mean square gradient fell below 0.05. The minimized structures are used for docking.

\subsection{Active site prediction.}

The active site was predicted by using the site finder option of using MOE software. The site finder option was used to calculate possible active sites from the 3D atomic coordinates. It is an energy-based method for predicting protein-ligand binding sites using a fast geometric algorithm based on Edelsbrunner's alpha shapes. Each site on a macromolecular structure is ranked according to its accessible hydrophobic contact surface. Visualizing individual sites or populating them with "dummy atoms" is used for docking calculations or starting points for de novo ligand design efforts.

\subsection{Ligand preparation.}

Using ACD/ChemSketch (12.0), the two-dimensional structures of all the compounds are drawn and saved in .mol file format. Figure 2 shows the 2D structure of sketched compounds. Further, the saved compounds are imported into MOE. The saved ligand compounds were later imported into MOE and refined using a systematic conformer search followed by geometry optimization and energy minimization of the lowest energy structure using the Merck Molecular Force Field (MMFF94). The individual compounds were finally saved in .mol file format for further binding studies.<smiles>COc1cc2ccnc(C)c2cc1OC</smiles>

Nigellicimine<smiles>Cc1cc(O)c2c(-c3ccc([O-])cc3)[n+]3n(c2c1)CCCC3</smiles>

Nigellidine<smiles>COc1cc2cc[n+]([O-])c(C)c2cc1OC</smiles>

Nigellicimine N-Oxide<smiles>Cc1cc(O)c2c(C(=O)[O-])[n+]3n(c2c1)CCCC3</smiles>

Nigellicine

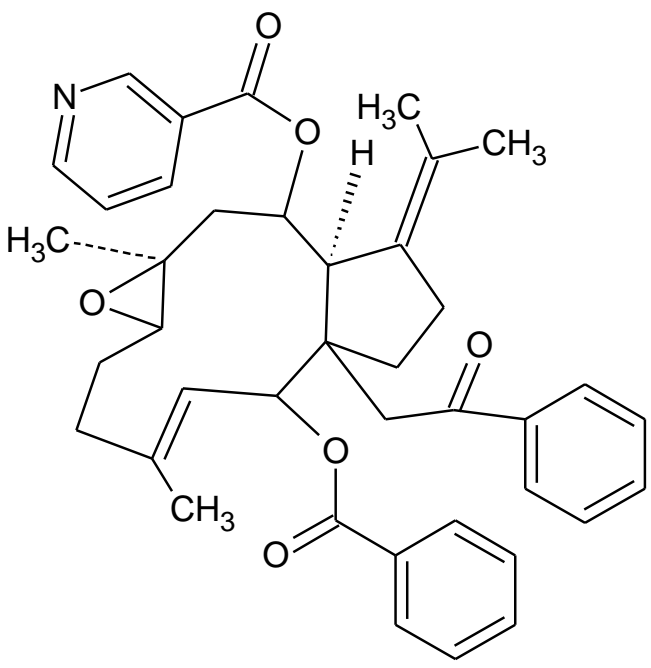

Nigellamine A1 


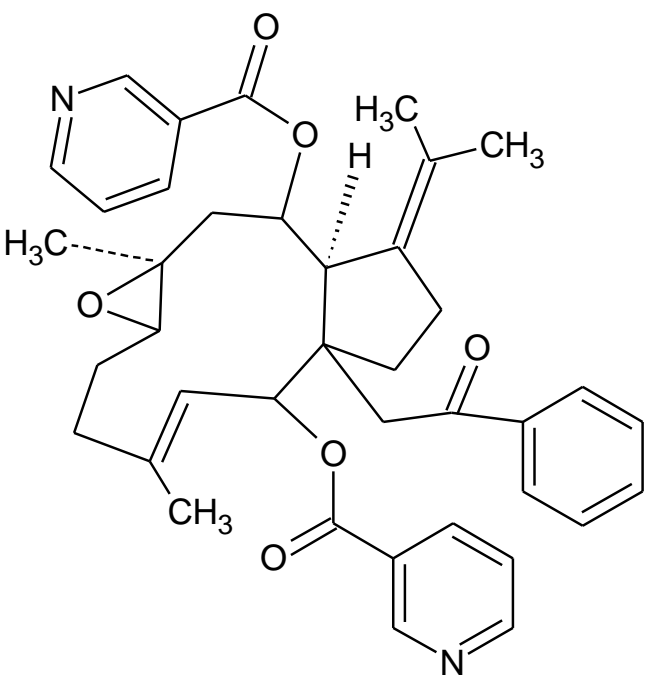

Nigellamine A2

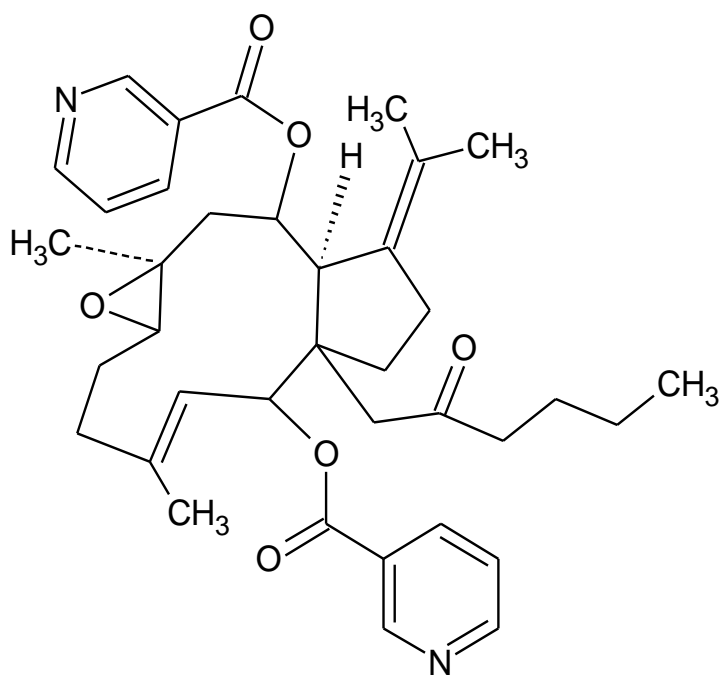

Nigellamine A4<smiles>CCCCCCC(=O)CC12CCC(=C(C)C)[C@H]1[C@H](OC(=O)c1cccnc1)C[C@@]1(C)OC1CC/C(C)=C/C2OC(=O)c1cccnc1</smiles>

Nigellamine A3

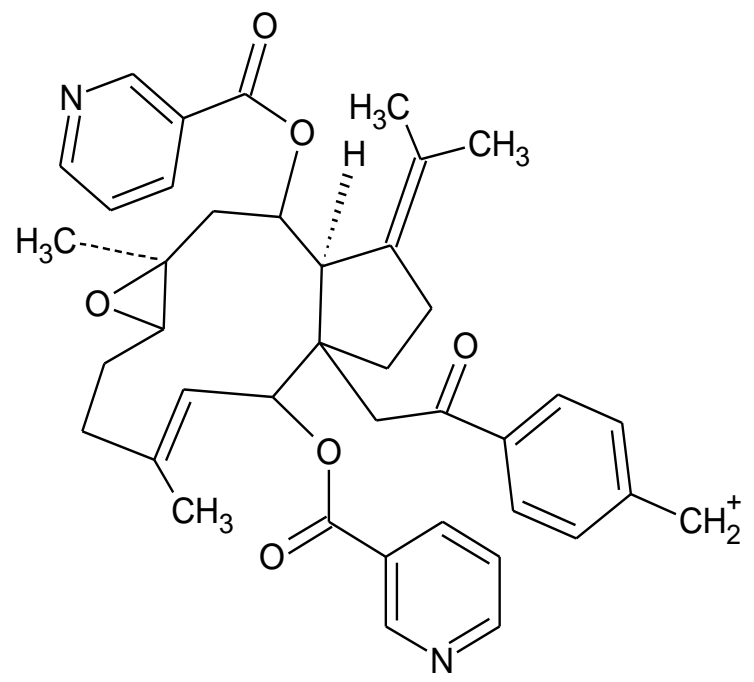

Nigellamine A5

Figure 2. Structures of the compounds from N.sativa.

\subsection{Molecular docking.}

Molecular docking is a reliable procedure that is used to predict binding poses for protein-ligand interactions. Thus, this facile study could be exploited to investigate molecular interaction and the most favorable binding site. In addition, the types of interactions based on the distance between the atoms in the amino acid and ligand could also be determined. After the ligands and proteins are energy minimized, we proceed to position the ligands in the active site of the proteins. For this, we used the molecular docking module using MOE docking program to find the correct conformation (with the rotation of bonds, structure of the molecule is not rigid) and configuration (with the rotation of the whole molecule, structure of the molecule remains rigid) of the ligand, to obtain minimum energy structure. The parameters used for the docking were, Total Runs $=50$, Cycle/Runs $=15$, Iteration Limit $=10000$, Potential Energy Grid: ON, Annealing Algorithm: Simulated Annealing. While performing docking, the ligand atom was selected, and rescoring1 was set at London $\mathrm{dG}$ and rescoring2 at GBVI/WSA $\mathrm{dG}$, running to note the ligand interaction with protein. The ligand-receptor complex will adopt the most stable conformation, i.e., the lowest energy level after it has been established. The 
dock application is used to look for the ligand-protein conformational binding that is beneficial. For each compound, several poses were generated to identify favorable binding modes. The best confirmation of each compound-protein complex was designated based on their energy. Among them, the conformation with the lowest docking score was chosen to study the binding orientations of the ligands, and each complex was assessed.

\section{Results and Discussion}

Proteins were prepared for molecular docking by 3D protonation, energy minimization, and prediction of the active site for ligands, keeping the parameters at their defaults. Next, ligands were docked with the target protein using MOE software. The prepared ligands are docked in the respective active site of both the proteins individually. Various conformations are predicted, and the best conformation for each protein complex was selected based on the lowest binding energy. Binding energy data obtained after the docking procedure showed that they exhibit favorable docked complex with the target, and the results are tabulated in Tables 1 and 2. The calculations were also used to predict protein-material complex structures and to study possible interactions based on $\mathrm{H}$-bonding, $\pi-\pi$, and arene- $\pi$ interactions. These docking experiments indicated that the molecules are good enough to act as 6LU7 and 6MOJ inhibitors.

\subsection{Docking analysis with main protease (6LU7).}

Among all docking conformations, the obtained results showed that compounds Nigellicine followed by Nigellicimine N-Oxide gives the lowest binding energy of -12.2351 $\mathrm{kcal} / \mathrm{mol}$ and $-12.2064 \mathrm{kcal} / \mathrm{mol}$, respectively in complex with the active residues of main protease ( 6LU7), which is the best score when compared to other docked compounds. Both these compounds have good inhibitory activity, and both these ligands exhibited a good interaction with the main protease (6LU7).

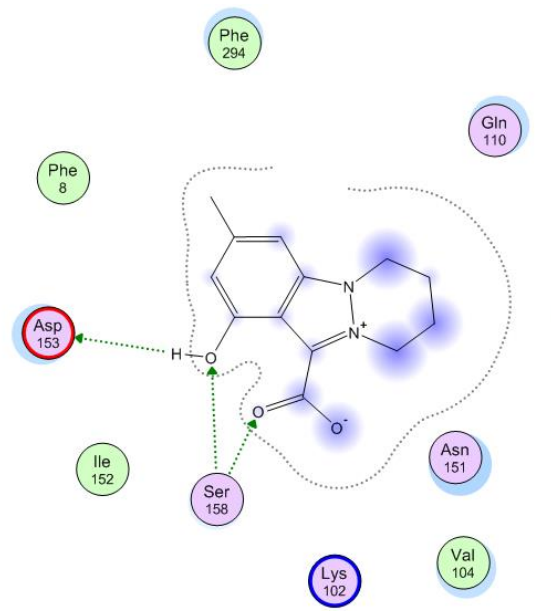

(A)

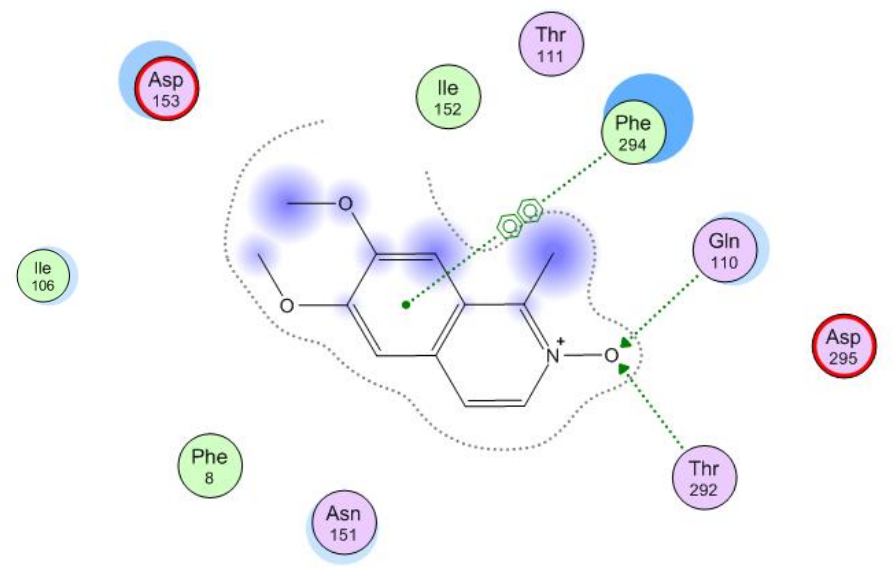

(B)

Figure 3. Docked conformations of the ligands (A) Nigellicine; (B) Nigellicimine N-Oxide with the active residues of main protease (6LU7).

The most potent ligand, Nigellicine, in complex with 6LU7 (Figure 3A), shows three hydrogen bond interactions, one with amino acid Asp153 and two with Ser158. Asp153 was observed to make a hydrogen bond, with the oxygen atom bonding with the hydrogen of the ligand(Nigellicine:H---OD:Asp153) with a hydrogen bond distance of $2.75 \AA$. Ser 158 formed two hydrogen bonds between an oxygen atom bonding with the hydrogen atom of the compound (Nigellicine:H---OG:Ser158 and Nigellicine:H---OG:Ser158) with a bond distance 
of $3.08 \AA$ and $2.45 \AA$. The compound Nigellicimine N-Oxide formed two hydrogen bond interactions with the protein 6LU7 (Figure 3B). The hydrogen bonds are formed with the oxygen atom of the compound and the Gln110 (Nigellicimine N-Oxide:O--NE:GLN110) and Thr 292 (Nigellicimine N-Oxide:O--OG:THR) with a hydrogen bond distance of $3.04 \AA$ and $3.08 \AA$, respectively. This compound was found to form an arene-arene $\pi$-stacking interaction with Phe 294. Interactions between the compounds from Nigella sativa and with the active residues of main protease (6LU7) are reported in table 1 and shown in Figure 3.

Table 1. Molecular Docking results of Compounds from Nigella sativa with the active residues of main protease (6LU7).

\begin{tabular}{|c|c|c|c|c|c|c|c|}
\hline $\begin{array}{l}\text { Name of } \\
\text { Molecule }\end{array}$ & $\mathbf{S}$ & E_conf & E_Place & E_Score1 & $\begin{array}{c}\text { Interacting amino } \\
\text { acids }\end{array}$ & Interacting atoms & H-distance \\
\hline Nigellicimine & -9.0376 & 2.4000 & -52.8179 & -9.0376 & $\begin{array}{l}\text { Phe8,Ile106 } \\
\text { Gln110,Phe294 } \\
\text { Ser158,Val104 } \\
\text { Ile152,Lys102 }\end{array}$ & $\begin{array}{l}\text { Nigellicimine:O........NE: } \\
\text { GLN110 } \\
\text { Nigellicimine:O........NE: } \\
\text { THR111 }\end{array}$ & $\begin{array}{l}3.18 \\
2.77\end{array}$ \\
\hline Nigellicine & -12.2351 & 0.0014 & -54.212 & -12.2351 & $\begin{array}{l}\text { Phe8,Ile106 } \\
\text { Gln110,Phe294 } \\
\text { Ser158,Val104 } \\
\text { Ile152,Lys102 }\end{array}$ & $\begin{array}{l}\text { Nigellicine:H---OD:Asp153 } \\
\text { Nigellicine:O---OG:Ser158 } \\
\text { Nigellicine:H---OG:Ser158 } \\
\text { Nigellicine:H---OG:Ser158 }\end{array}$ & $\begin{array}{l}2.75 \\
3.08 \\
3.08 \\
2.45\end{array}$ \\
\hline Nigellidine & -10.3924 & 0.2000 & -30.4259 & -13.3924 & $\begin{array}{l}\text { Phe8,Ile106 } \\
\text { Gln110,Phe294 } \\
\text { Ser158,Val104 } \\
\text { Ile152,Lys102 } \\
\end{array}$ & $\begin{array}{l}\text { Nigellidine:O--- } \\
\text { ND:ASn151 }\end{array}$ & 2.62 \\
\hline $\begin{array}{l}\text { Nigellamine } \\
\text { A1 }\end{array}$ & -11.5523 & 3.9085 & -74.3466 & -11.5523 & $\begin{array}{l}\text { Phe8,Ile106 } \\
\text { Gln110,Phe294 } \\
\text { Ser158,Val104 } \\
\text { Ile152,Lys102 }\end{array}$ & $\begin{array}{l}\text { NigellamineA1:O---- } \\
\text { NH:Arg403 }\end{array}$ & 2.90 \\
\hline $\begin{array}{l}\text { Nigellamine } \\
\text { A2 }\end{array}$ & -9.6556 & 4.0346 & -98.2781 & -9.6556 & $\begin{array}{l}\text { Phe8,Ile106 } \\
\text { Gln110,Phe294 } \\
\text { Ser158,Val104 } \\
\text { Ile152,Lys102 }\end{array}$ & $\begin{array}{l}\text { NigellamineA2:O--ND- } \\
\text { Asn: } 142\end{array}$ & 2.70 \\
\hline $\begin{array}{l}\text { Nigellamine } \\
\text { A3 }\end{array}$ & -10.5144 & 2.8747 & -45.0242 & -10.5144 & $\begin{array}{l}\text { Phe8,Ile106 } \\
\text { Gln110,Phe294 } \\
\text { Ser158,Val104 } \\
\text { Ile152,Lys102 }\end{array}$ & $\begin{array}{l}\text { NigellamineA3:O--NE- } \\
\text { Gln:110 } \\
\text { NigellamineA3:O--OG- } \\
\text { Thr:292 }\end{array}$ & $\begin{array}{l}2.71 \\
3.13\end{array}$ \\
\hline $\begin{array}{l}\text { Nigellamine } \\
\text { A4 }\end{array}$ & -9.9857 & 3.7995 & -59.5621 & -9.9857 & $\begin{array}{l}\text { Phe8,Ile106 } \\
\text { Gln110,Phe294 } \\
\text { Ser158,Val104 } \\
\text { Ile152,Lys102 }\end{array}$ & - & - \\
\hline $\begin{array}{l}\text { Nigellamine } \\
\text { A5 }\end{array}$ & -11.0797 & 4.1345 & -47.1449 & -11.0797 & $\begin{array}{l}\text { Phe8,Ile106 } \\
\text { Gln110,Phe294 } \\
\text { Ser158,Val104 } \\
\text { Ile152,Lys102 }\end{array}$ & $\begin{array}{l}\text { NigellamineA5:O-- } \\
\text { NE:Gln110 }\end{array}$ & 2.33 \\
\hline $\begin{array}{l}\text { Nigellicimine } \\
\text { N-Oxide }\end{array}$ & -12.2046 & 3.1670 & -57.3462 & -12.2046 & $\begin{array}{l}\text { Phe8,Ile106 } \\
\text { Gln110,Phe294 } \\
\text { Ser158,Val104 } \\
\text { Ile152,Lys102 }\end{array}$ & $\begin{array}{l}\text { Nigellicimine N-Oxide:O-- } \\
\text { NE:GLN110 } \\
\text { Nigellicimine N-Oxide:O-- } \\
\text { OG:THR }\end{array}$ & $\begin{array}{l}3.04 \\
3.08\end{array}$ \\
\hline
\end{tabular}

3.2. Docking analysis with spike receptor-binding domain(6MOJ).

Among all docking conformations, the obtained results showed that compounds Nigellamine A5 followed by Nigellamine A1 gives the lowest binding energy of -12.5858 $\mathrm{kcal} / \mathrm{mol}$ and $-12.1332 \mathrm{kcal} / \mathrm{mol}$, respectively in complex with spike receptor-binding domain( $6 \mathrm{MOJ}$ ), which is the best score when compared to other docked compounds. Both these compounds have good inhibitory activity, and both these ligands exhibited a good interaction 
with the spike receptor-binding domain (6MOJ). The most potent ligand, Nigellamine A5 in complex with protein (Figure 4A), shows two hydrogen bond interactions, each with amino acids Tyr453 and Tyr 449. Tyr 499 was observed to make a hydrogen bond, with the oxygen atom bonding with the hydrogen of the ligand (NigellamineA5:O--OH:Tyr449) with a hydrogen bond distance of $3.34 \AA$. Tyr 453 formed a hydrogen bond between an oxygen atom bonding with the hydrogen atom of the compound (NigellamineA5:O--OH:Tyr453) with a bond distance of $2.31 \AA$. The compound Nigellamine A1 formed a single hydrogen bond interaction with the protein 6MOJ (Figure 4B ). It is formed with the oxygen atom of the compound and the residue Arg403 (NigellamineA1:O----NH:Arg403) with a hydrogen bond distance of $2.90 \AA$. Interactions between the compounds from Nigella sativa and with the active residues of spike receptor-binding domain (6MOJ) are reported in Table 2 and shown in Figure 4.

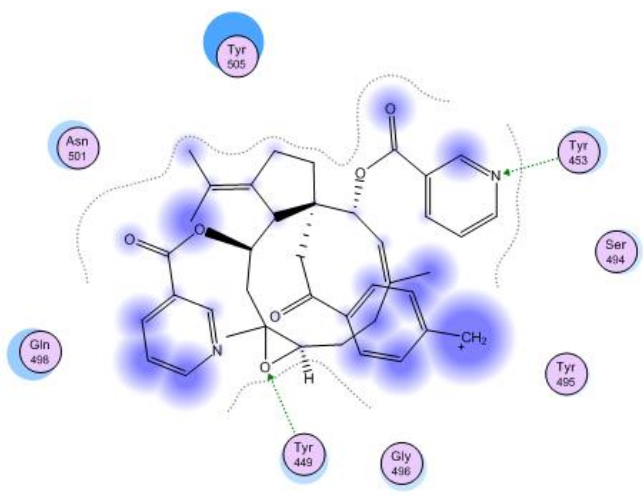

A

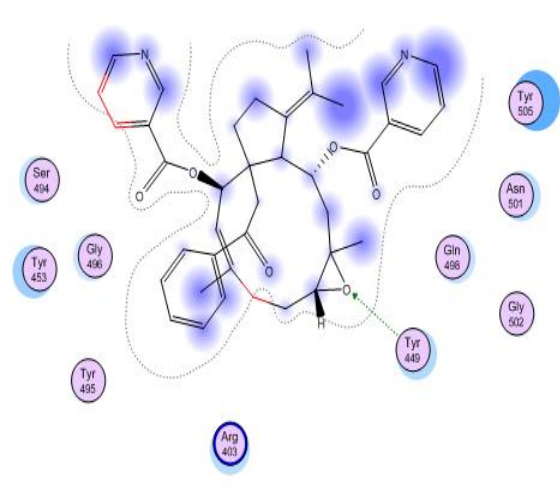

B

Figure 4. Docked conformations of the ligands (A) Nigellamine A5; (B) Nigellamine A1 with the active residues of spike receptor-binding domain $(6 \mathrm{MOJ})$.

Table 2. Molecular docking results of compounds from Nigella sativa with the active residues of spike receptor-

\begin{tabular}{|c|c|c|c|c|c|c|c|}
\hline \multirow{2}{*}{$\begin{array}{l}\begin{array}{l}\text { Name of } \\
\text { Molecule }\end{array} \\
\text { Nigellicimine }\end{array}$} & \multirow{2}{*}{\begin{tabular}{|l|}
$\mathbf{S}$ \\
-9.0376
\end{tabular}} & \multirow{2}{*}{$\begin{array}{c}\text { E_conf } \\
2.4000\end{array}$} & \multirow{2}{*}{$\begin{array}{l}\text { E_Place } \\
-52.8179\end{array}$} & \multicolumn{2}{|c|}{ binding domain (6MOJ). } & \multirow[b]{2}{*}{ Interacting atoms } & \multirow[b]{2}{*}{ H-distance } \\
\hline & & & & E_Score1 & $\begin{array}{l}\text { Interacting amino } \\
\text { acids }\end{array}$ & & \\
\hline Nigellicimine & -9.0376 & 2.4000 & -52.8179 & -9.0376 & $\begin{array}{l}\text { Arg403,Glu406 } \\
\text { Lys417,Tyr453 } \\
\text { Ser494,Tyr495 } \\
\text { Gly496,Phe497 } \\
\text { Asn501, Tyr505 }\end{array}$ & $\begin{array}{l}\text { Nigellicimine:O........NH: } 1092 \\
\text { ARG }\end{array}$ & 3.37 \\
\hline Nigellicine & -11.3837 & 0.0014 & -66.3831 & -11.3837 & $\begin{array}{l}\text { Arg403,Glu406 } \\
\text { Lys417,Tyr453 } \\
\text { Ser494,Tyr495 } \\
\text { Gly496,Phe497 } \\
\text { Asn501, Tyr505 }\end{array}$ & Nigellicine:O---OH:Tyr505 & 2.83 \\
\hline Nigellidine & -10.0659 & 0.2000 & -53.7244 & -10.0659 & $\begin{array}{l}\text { Arg403, Glu406 } \\
\text { Lys417,Tyr453 } \\
\text { Ser494,Tyr495 } \\
\text { Gly496,Phe497 } \\
\text { Asn501, Tyr505 } \\
\end{array}$ & $\begin{array}{l}\text { Nigellidine:O---NE:Gln409 } \\
\text { Nigellidine:O---NE:Lys417 } \\
\text { Nigellidine:O---NE:Ile418 }\end{array}$ & $\begin{array}{l}2.40 \\
2.87 \\
3.14\end{array}$ \\
\hline $\begin{array}{l}\text { Nigellamine } \\
\text { A1 }\end{array}$ & -12.1332 & 3.1736 & -59.5286 & -12.1332 & $\begin{array}{l}\text { Arg403, Glu406 } \\
\text { Lys417,Tyr453 } \\
\text { Ser494,Tyr495 } \\
\text { Gly496,Phe497 } \\
\text { Asn501, Tyr505 }\end{array}$ & NigellamineA1:O----NH:Arg403 & 2.90 \\
\hline $\begin{array}{l}\text { Nigellamine } \\
\text { A2 }\end{array}$ & -10.1479 & 4.0124 & -36.2572 & -10.1479 & $\begin{array}{l}\text { Arg403, Glu406 } \\
\text { Lys417,Tyr453 } \\
\text { Ser494,Tyr495 } \\
\text { Gly496,Phe497 } \\
\text { Asn501, Tyr505 }\end{array}$ & NigellamineA2:O--OH-Tyr:449 & 3.02 \\
\hline
\end{tabular}




\begin{tabular}{|c|c|c|c|c|c|c|c|}
\hline $\begin{array}{l}\text { Name of } \\
\text { Molecule }\end{array}$ & $\mathbf{S}$ & E_conf & E_Place & E_Score1 & $\begin{array}{l}\text { Interacting amino } \\
\text { acids }\end{array}$ & Interacting atoms & H-distance \\
\hline $\begin{array}{l}\text { Nigellamine } \\
\text { A3 }\end{array}$ & -11.7104 & 3.6000 & -64.7073 & -11.7104 & $\begin{array}{l}\text { Arg403,Glu406 } \\
\text { Lys417,Tyr453 } \\
\text { Ser494,Tyr495 } \\
\text { Gly496,Phe497 } \\
\text { Asn501, Tyr505 }\end{array}$ & NigellamineA3:O--OH-Tyr:449 & 2.50 \\
\hline $\begin{array}{l}\text { Nigellamine } \\
\text { A4 }\end{array}$ & -10.3770 & 4.1080 & -72.2176 & -10.3770 & $\begin{array}{l}\text { Arg403,Glu406 } \\
\text { Lys417,Tyr453 } \\
\text { Ser494,Tyr495 } \\
\text { Gly496,Phe497 } \\
\text { Asn501, Tyr505 } \\
\end{array}$ & NigellamineA4:O--OH-Tyr:449 & 2.51 \\
\hline $\begin{array}{l}\text { Nigellamine } \\
\text { A5 }\end{array}$ & -12.5858 & 2.5781 & -46.3674 & -12.5858 & $\begin{array}{l}\text { Arg403,Glu406 } \\
\text { Lys417,Tyr453 } \\
\text { Ser494,Tyr495 } \\
\text { Gly496,Phe497 } \\
\text { Asn501, Tyr505 }\end{array}$ & $\begin{array}{l}\text { NigellamineA5:O--OH:Tyr449 } \\
\text { NigellamineA5:O--OH:Tyr453 }\end{array}$ & $\begin{array}{l}3.34 \\
2.31\end{array}$ \\
\hline $\begin{array}{l}\text { Nigellicimine } \\
\text { N-Oxide }\end{array}$ & -10.4018 & 2.4000 & -48.5022 & -10.4018 & $\begin{array}{l}\text { Arg403, Glu406 } \\
\text { Lys417,Tyr453 } \\
\text { Ser494,Tyr495 } \\
\text { Gly496,Phe497 } \\
\text { Asn501, Tyr505 }\end{array}$ & $\begin{array}{ll}\text { Nigellicimine } & \text { N-Oxide:O-- } \\
\text { NH:Arg403 } & \\
\text { Nigellicimine } & \text { N-Oxide:O-- } \\
\text { NH:Arg403 } & \end{array}$ & $\begin{array}{l}2.84 \\
2.82\end{array}$ \\
\hline
\end{tabular}

\section{Conclusions}

Considering the global threat posed by SARS CoV-2, with no proven antiviral agent available for immediate relief. The present molecular docking study explores us to find new ligands from active constituents of Nigella sativa, which can dock on the main protease and spike glycoprotein of SARS-CoV2 to block the viral pathogenesis. The results showed that Nigellicine and Nigellicimine N-Oxide against the main protease and Nigellamine A5 and Nigellamine A1 against spike glycoprotein are main compounds from Nigella sativa possessed striking interactions with better binding affinity. Future studies should more carefully examine the clinical efficacy of these compounds, thus facilitating the development of novel resources for the treatment of COVID-19 and encouraging the traditional use of Nigella sativa preventively.

\section{Funding}

This research had no funding.

\section{Acknowledgments}

This research has no acknowledgment.

\section{Conflicts of Interest}

The authors delicate no conflict of interest among them.

\section{References}

1. Ji, W.; Wang, W.; Zhao, X.; Zai, J.; Li, X. Cross-species transmission of the newly identified coronavirus 2019-nCoV. J. Med. Virol. 2020, 92, 433-440, https://doi.org/10.1002/jmv.25682.

2. Zhou, Y.; Hou, Y.; Shen, J.; Huang, Y.; Martin, W.; Cheng, F. Network-based drug repurposing for novel coronavirus 2019-nCoV/SARS-CoV-2. Cell Discovery 2020, 6, 14, https://doi.org/10.1038/s41421-0200153-3.

3. Rothan, H.A.; Byrareddy, S.N. The epidemiology and pathogenesis of coronavirus disease (COVID-19) outbreak. J. Autoimmun. 2020, 109, 102433, https://doi.org/10.1016/j.jaut.2020.102433. 
4. Velavan, T.P.; Meyer, C.G. The COVID-19 epidemic. Trop. Med. Int. Health 2020, 25, 278-280, https://doi.org/10.1111/tmi.13383.

5. Lee, P.-I.; Hsueh, P.-R. Emerging threats from zoonotic coronaviruses-from SARS and MERS to 2019-nCoV. J. Microbiol. Immunol. Infect. 2020, 53, 365-367, https://doi.org/10.1016/j.jmii.2020.02.001.

6. Coronavirus disease (COVID-2019) situation reports-86, 15 April 2020, World Health Organization, 2020.

7. Lu, R.; Zhao, X.; Li, J.; Niu, P.; Yang, B.; Wu, H.; Wang, W.; Song, H.; Huang, B.; Zhu, N. Genomic characterisation and epidemiology of 2019 novel coronavirus: implications for virus origins and receptor binding. The lancet 2020, 395, 565-574, https://doi.org/10.1016/S0140-6736(20)30251-8.

8. Wu, F.; Zhao, S.; Yu, B.; Chen, Y.-M.; Wang, W.; Song, Z.-G.; Hu, Y.; Tao, Z.-W.; Tian, J.-H.; Pei, Y.-Y.; Yuan, M.-L.; Zhang, Y.-L.; Dai, F.-H.; Liu, Y.; Wang, Q.-M.; Zheng, J.-J.; Xu, L.; Holmes, E.C.; Zhang, Y.Z. A new coronavirus associated with human respiratory disease in China. Nature 2020, 579, 265-269, https://doi.org/10.1038/s41586-020-2008-3.

9. Chen, Y.; Liu, Q.; Guo, D. Emerging coronaviruses: Genome structure, replication, and pathogenesis. J. Med. Virol. 2020, 92, 418-423, https://doi.org/10.1002/jmv.25681.

10. Wafa, T.; Mohamed, K. Molecular docking study of COVID-19 main protease with clinically approved drugs. ChemRxiv. Preprint. https://doi.org/10.26434/chemrxiv.12318689.v1.

11. Bzówka, M.; Mitusińska, K.; Raczyńska, A.; Samol, A.; Tuszyński, J.A.; Góra, A. Structural and Evolutionary Analysis Indicate That the SARS-CoV-2 Mpro Is a Challenging Target for Small-Molecule Inhibitor Design. Int. J. Mol. Sci. 2020, 21, https://doi.org/10.3390/ijms21093099.

12. Li, F. Structure, Function, and Evolution of Coronavirus Spike Proteins. Annual Review of Virology 2016, 3 , 237-261, https://doi.org/10.1146/annurev-virology-110615-042301.

13. Schoeman, D.; Fielding, B.C. Coronavirus envelope protein: current knowledge. Virol J. 2019, 16, 69, https://doi.org/10.1186/s12985-019-1182-0.

14. Lan, J.; Ge, J.; Yu, J.; Shan, S.; Zhou, H.; Fan, S.; Zhang, Q.; Shi, X.; Wang, Q.; Zhang, L.; Wang, X. Structure of the SARS-CoV-2 spike receptor-binding domain bound to the ACE2 receptor. Nature 2020, 581, 215-220, https://doi.org/10.1038/s41586-020-2180-5.

15. Joshi, T.; Joshi, T.; Sharma, P.; Mathpal, S.; Pundir, H.; Bhatt, V.; Chandra, S. In silico screening of natural compounds against COVID-19 by targeting Mpro and ACE2 using molecular docking. Eur. Rev. Med. Pharmacol. Sci. 2020, 24, 4529-4536, https://doi.org/10.26355/eurrev_202004_21036.

16. Ahmad, A.; Husain, A.; Mujeeb, M.; Khan, S.A.; Najmi, A.K.; Siddique, N.A.; Damanhouri, Z.A.; Anwar, F. A review on therapeutic potential of Nigella sativa: A miracle herb. Asian Pacific Journal of Tropical Biomedicine 2013, 3, 337-352, https://doi.org/10.1016/S2221-1691(13)60075-1.

17. Abel-Salam, B.K.A. Immunomodulatory effects of black seeds and garlic on alloxan-induced Diabetes in albino rat. Allergol. Immunopathol. (Madr.) 2012, 40, 336-340, https://doi.org/10.1016/j.aller.2011.07.002.

18. Khaled, A.A.S. Gastroprotective effects of Nigella sativa oil on the formation of stress gastritis in hypothyroidal rats. Int J Physiol Pathophysiol Pharmacol. 2009, 1, 143-149.

19. Assayed, M.E. Radioprotective effects of black seed (Nigella sativa) oil against hemopoietic damage and immunosuppression in gamma-irradiated rats. Immunopharmacol. Immunotoxicol. 2010, 32, 284-296, https://doi.org/10.3109/08923970903307552.

20. Abdel-Zaher, A.O.; Abdel-Rahman, M.S.; Elwasei, F.M. Protective effect of Nigella sativa oil against tramadol-induced tolerance and dependence in mice: Role of nitric oxide and oxidative stress. Neurotoxicology 2011, 32, 725-733, https://doi.org/10.1016/j.neuro.2011.08.001.

21. Boskabady, M.H.; Mohsenpoor, N.; Takaloo, L. Antiasthmatic effect of Nigella sativa in airways of asthmatic patients. Phytomedicine 2010, 17, 707-713, https://doi.org/10.1016/j.phymed.2010.01.002.

22. Goreja, W.G. Black seed: nature's miracle remedy. New York, NY: Amazing Herbs Press; 2003. 